\title{
Український медіаматерик на «Туманному альбіоні»: до виходу у світ двох монографій М. Тимошика про українську журналістику і книговидання в діаспорі ${ }^{1}$ \\ Ігор ПАВЛЮК \\ д-р н. із соц. комунік., проф. \\ Інститут літератури \\ ім. Т. Г. Шевченка НАНУ \\ вул. Грушевського, 4, \\ Київ, Україна, 02000 \\ pihor@ukr.net \\ (C) Павлюк I., 2021
}

Рецензія знайомить читача із результатами проведених професором Миколою Тимошиком в архівах та бібліотечних колекціях у Великій Британії досліджень історії української журналістики і книговидання на британських островах. Ці результати подані у двох книгах, що рекомендовані до друку Вченою радою Київського національного університету культури і мистецтв: «Українська журналістика в діаспорі: Велика Британія» та «Українське книговидання в діаспорі: Велика Британія». Книги вийшли друком у київському видавництві «Наша культура і наука» 2021 року.

У першій книзі вперше узагальнено й осмислено в ретроспективі феномен журналістської діяльності українців у Великій Британії. У хронологічній послідовності висвітлюються становлення, здобутки та проблеми головних редакційних осередків за такими напрямами: агенційна, газетна, журнальна, радійна журналістика. Окремо йдеться про англомовну періодику та про місію і кредо українського журналіста на чужині.

У другій книзі віднайдено й описано сліди діяльності перших друкарень та книгарень у цій країні. У хронологічній послідовності висвітлюється становлення, здобутки та проблеми головних видавництв і видавничих осередків. Окремо йдеться про англомовний сегмент друкованої продукції українців для чужинців та про серію антирадянських видань, що переправлялися до СРСР. Уперше подано упорядкований автором каталог видань українців у Великій Британії.

Для журналістів, викладачів, науковців, дипломатів, студентів, усіх, хто цікавиться історією української еміграції.

1 Рецензія на книги:

- Тимошик М. С. Українська журналістика в діаспорі: Велика Британія. Київ: Наша культура і наука, 2021. 512 с.;

- Тимошик М. С. Українське книговидання в діаспорі: Велика Британія. Київ: Наша культура і наука, 2021. 484 с. 


\title{
UKRAINIAN MEDIA MAINLAND ON THE "FOGGY ALBION": DEDICATED TO PUBLISHING OF TWO MONOGRAPHS BY M. TYMOSHYK ON UKRAINIAN JOURNALISM AND BOOK PUBLISHING IN THE DIASPORA ${ }^{2}$
}

\author{
Ihor Pavliuk \\ Doctor of Social Communications, Professor \\ Shevchenko Institute of Literature \\ The National Academy of Sciences of Ukraine \\ 4, Hrushevskoho St., Kyiv, Ukraine, 02000 \\ pihor@ukr.net
}

The review introduces the reader to the results of Professor Mykola Tymoshyk's research in archives and library collections in Great Britain on the history of Ukrainian journalism and book publishing on the British Isles. The author submitted these results in two books recommended for printing by the Academic Council of Kyiv National University of Culture and Arts: "Ukrainian Journalism in the Diaspora: Great Britain" and "Ukrainian book publishing in the diaspora: Great Britain". The books were published in Kyiv publishing house "Our Culture and Science" in 2021.

The first book, for the first time, generalized and comprehensive in the retrospective of the phenomenon of journalistic activity of Ukrainians in the UK. The chronological sequence illuminates the formation, achievements, and problems of the principal editorial cells in the following areas: agencies, newspaper, magazine, broadcast journalism. Separately, it is about English-language periodicals and a mission and credo of a Ukrainian journalist abroad.

The second book finds and describes traces of the first printing houses and bookstores activities in this country. The chronological sequence highlights the formation, achievements, and problems of major publishers and publishing houses. Separately, the book shows the English-language segment of Ukrainian printed materials for foreigners and a series of anti-Soviet publications that were transferred to the USSR. For the first time, a catalog of Ukrainian publications in Great Britain, edited by the author, was presented.

For journalists, teachers, scientists, diplomats, students, anyone interested in the history of Ukrainian emigration.

2 Рецензія на книги:

- Тимошик М. С. Українська журналістика в діаспорі: Велика Британія. Київ: Наша культура і наука, 2021. 512 с.;

- Тимошик М. С. Українське книговидання в діаспорі: Велика Британія. Київ: Наша культура і наука, 2021. 484 с. 


\section{Чин літератора і вченого-гуманітарія як духовного воїна}

Микола Тимошик із тих гуманітаріїв-професорів, діапазон діяльності яких знаково ширший за межі вузькоспеціальних дисциплін - теоpiї, історії і практики журналістики, видавничої справи та літератури.

Відомий журналіст, публіцист та учений, один із першовідкривачів для сучасників духовного материка під назвою «Іван Огієнко», двотомника «Село» («своєрідної енциклопедії життя українського села» - за словами Степана Колесника), за який став лауреатом Народної Шевченківської премії, професор Микола Тимошик - реальний духовний воїн на культурно-інформаційному національному полі з експансивними виходами

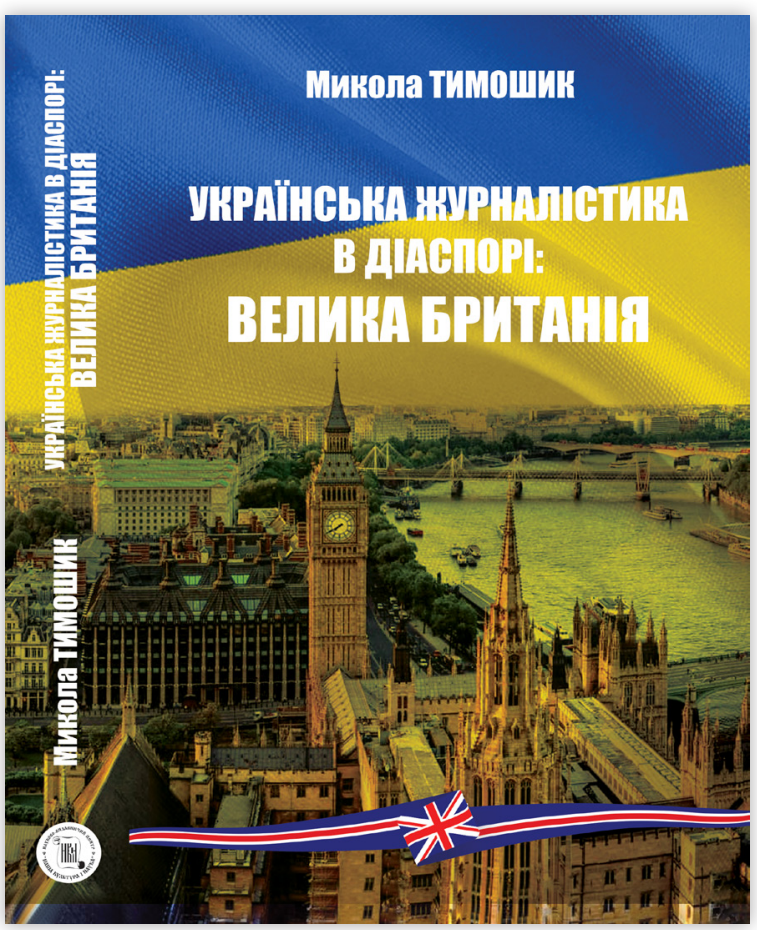
на діаспорний і світовий духовні простори.

Чого варті його низка книг та лекційні виступи в навчальних і наукових закладах Бельгії, Великої Британії, Іспанії, Ізраїлю, Канади, Китаю, Німеччини, Польщі, Росії, Сербії, Франції, Швейцарії, Швеції, який одним iз перших прилюдно повстав проти профанації національної освіти і науки, оприлюднивши свою статтю «Українська гуманітарна наука під дамоклевим мечем «Скопусу» (Тимошик, 2021a) й організувавши «Відкрите звернення до державного керівництва», тобто на чинний захист того, що сказав: «Куди й ким спрямована національна університетська освіта і наука?» («Куди і ким спрямована», 2021), «В Україні назріває «науковий переворот» - освітяни звернулися до Зеленського через глибоку кризу. Серед вимог - невідкладний розгляд наболілих питань у Парламенті (Романова, 2021).

Читаю численні інтерв'ю із ним, де він сам розповідає про текст, контекст, підтекст, надтекст творення його книг, його подорожей у часі і просторі, часопросторі.

Тобто слово і чин, текст і життєтекст гармонійно поєднуються в особі-особистості Миколи Степановича Тимошика, який не перестає дивувати-зацікавлювати нас і нащадків новими громадськими 
ініціативами-викликами та свіжими дослідженнями - 1000-сторінковою українсько-британською епопеєю. Він надіслав мені їх із написом: «Вельмишановному Докторові і Поетові Ігореві Павлюку - діаспорна тема і далі залишається для українських учених неораною Цілиною. Пробуймо «брати» ї̈ своїми сериями. Автор. 18.01.21».

«Ці дві книги уводять читача в дивний, не пізнаний і не поцінований нами світ української еміграції. Розглядаю його і як явище національної історії, і як феномен нерозв’язаного понині світовою спільнотою «українського питання», і як місію захисту українського в Україні, і як чин служіння національній ідеї [...]. Зібраного матеріалу виявилося настільки багато, що довелося замість однієї книги робити дві. А щодо «загублення в нетрях тексту», то маю свою власну методу написання: сюжетний розвиток подій, інтрига окремих фактів, емоційні домінанти, публіцистична тональність викладу. Це зазвичай тримає увагу читача, спонукає його шукати в тексті відповіді на запитання: а що, як і чому було далі? I то незалежно - йдеться про підручник, монографію чи документально-публіцистичну оповідь» - розповідає професор

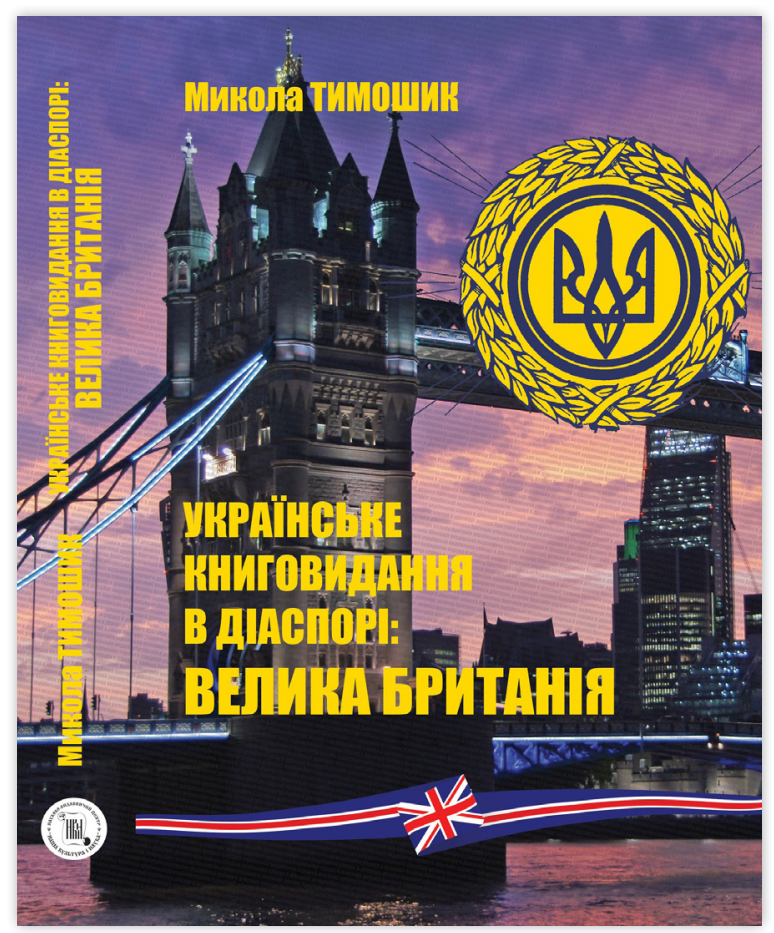
Микола Тимошик про рідну Чернігівщину, українську діаспору у своєму інтерв’ю «Материн заповіт у вишитому 1933 року рушнику» головній редакторці щотижневого видання про українську і світову науку «Граніт Науки» Дарії Тарусовій (Тимошик, 2021b).

Це направду вдається авторові, про що свідчить наше ближче знайомство із його книгами.

\section{Незнана в себе вдома українська преса на чужині}

Рецензувати британське двокнижжя Миколи Тимошика для мене було особливо цікаво, адже віддавна сам вивчаю українську пресу, мав творчі виступи в Лондоні, де британці надрукували добірку моїх віршів «A Flight Over the Black Sea». 
Ці ж книги - аргументоване і всеосяжне жовто-синє заповнення ще однієї «білої плями» в історії українців на чужині. Направду це $\epsilon$ першим осмислено-узагальненим, хронологізованим, органічно диференційованим за головними редакційними осередками та видами журналістики, відкриттям культурно-інформаційного материка журналістської діяльності українців, яких доля закинула в цю країну і які формували і відстоювали принципи української журналістики на чужині, апріорі впливаючи на свідомість українців і «чужинців» у материковій Україні, в усьому світі на всі часи.

Не випадково автор узяв кредовим епіграфом до першої книги слова духовного генерала культурно-ідеологічної битви за Україну Івана Багряного: «... Наша преса, народжена під Дамоклевим мечем репатріації..., не тільки вистояла і вціліла донині, а й виявила блискучу здібність рости й розвиватися... I цим поставлено дійсно непроминальний приклад - як «голота», що прийшла на Захід без гроша за душею, може та вміє діяти так організовано; у якій мірі сучасна «збільшовичена» та «зденаціоналізована» окупантом людина здібна до збірної масової акції». У своєму «Від автора» коротко й сильно дослідник подає своєрідний синопсис масштабної праці: історію своєї причетності до діаспорного тексту, контексту, дискурсу, дякуючи організаціям та людям, які допомагали йому.

Про масштабність зробленого колегою засвідчують оригінальний «Вступ» («Історія питання та його актуальність», «Феномен української еміграції та етапи формування», «Специфіка, осередки та етапи української еміграції у Великій Британії), та не менш оригінальні сім журналістикознавчих розділів («Місія і кредо українського журналіста на чужині», «Пресове бюро як вид агенційної журналістики», «Газетна журналістика», «Журнальна журналістика», «Радійна журналістика», «Англомовна журналістика», «Резонансні акції українців в оцінці преси») із численними підзаголовками в кожному, що формують колосальну за обсягом дослідженого архівного та емпіричного матеріалу і глибиною змісту сюжетну канву розповіді. Крім «Висновків» у монографії присутні такі додаткові структурні складники, які вивищують будь-яке наукове дослідження: «Абревіатури, що зустрічаються в тексті книги»; іменний та предметний показники; «Summary» (англійською та німецькою мовами); «Основні праці автора $з$ історії, теорії і практики української журналістики і книговидання на чужині». Тут подано також інтерв’ю професора Миколи Тимошика лондонській газеті «Українська Думка» (розмову вела Людмила Пекарська) під назвою «Українська книга і преса на чужині», опубліковане в Лондоні 2 квітня 2016 року.

Серед найцікавіших, знакових підрозділів книги, які власне і маркують її всеохопно-деталізований обшир, ємко й переконливо випи- 
сані ракурси всіх сфер організованого життя українських емігрантів на чужині (від заснування церков, шкіл, освітніх осередків до редакцій газет і журналів: «Про газетні війни між своїми», «Мораль і журналістика», «Проєкт катедри журналістики при УВУ в Мюнхені», «Стосунки 3 головним проводом еміграції», «Акція компрометації у пресі силами своїх», «Оцінка чужинців», «Наклади, видатки і гонорари», «Перший журнал із військової журналістики», «Літопис історії церкви», «Протести адептів «русского міра» $з$ Парижа, Москви та Києва», «Про факти утисків поляками українців на Галичині», «Промотор ідеї Гетьманської України», «Ситуація з вимушеними втікачами після Другої світової війни», «Англомовна періодика українців - на постійній основі», «На волю у вільному світі мали право не всі», «Синьо-жовтий стяг проти серпа і молота»...

Важлива акцентуація уваги автора на військовій періодиці («Сурмач»), церковних часописах («Наша Церква», «Відомості єпархіального Управління УАПЦ у Великій Британії»), періодичних виданнях для дітей, народжених у діаспорі, як-от на часописі «Юні Друзі» в параграфі «Що необхідно знати кожній українській дитині?» тощо.

Радійна журналістика в заявленому контексті репрезентована низкою мало не детективних сюжетів про із радіостанцій «Голос Америки», «Бі-Бі-Сі», українська англомовна журналістика - дипломатичним виданням «The Ukraine», «The Investigator», «The Ukrainian Review» та багатьма іншими. Контекстуальна увага природно приділена організаторам та іншим учасникам творення української журналістики у Великій Британії, серед яких Теодор Данилів, Ілля Дмитрів, Григорій Драбат, Ірена Збудовська, Зиновій Карбович, Володимир Кисілівський, Теодор Кудлик, Євген Ляхович, Маркіян Меленевський, Михайло Омелянович-Павленко, Софія Русова, Григорій Цебрій, Андрій Шуль, Дмитро Штикало...

Книга легка для читання, важка для переживання, фактологічно насичена, оптимально емоційно забарвлена, навіть певною мірою охудожнена енциклопедія пульсуючого буття українського національного культурно-інформаційного часопростору, боротьби за ідентичність, «головне завдання - промоцію України»...

\section{Чим була українська книга для емігрантів}

Становлення організованого життя тої чи тої національної спільноти на чужині гуманітарно й навіть технічно пов'язане з публікацією книг тією ж мовою чи кількома мовами, але націєцентричних.

Зазвичай цей процес взаємопов'язаний. Редакції газет та журналів часто засновували видавництва книг, книгарні для їхнього продажу, читання, популяризували ці книги через друк рецензій на українські книги. I - навпаки: книгарні популяризували відповід- 
ні часописи, а самі письменники часто були й журналістами, видавцями.

Свідчення таких тенденцій наступна книга цього автора - «Українське книговидання в діаспорі: Велика Британія» із присвятою «світлої пам'яти колишньої президентки видавничої спілки «Тризуб», редакторки, журналістки, громадської діячки з канадського Вінніпега - Анни Фігус-Ралько, яка благословила мене на вивчення та промоцію феномену Української Діаспори».

Створена автором, як і згадувана нами попередня, на основі опрацьованих архівів та бібліотечних сховищ у Великій Британії. Тут уперше системно оприявлено «феномен книговидавничої діяльности українців на чужині» із віднайденням слідів перших друкарень та книгарень у «Туманному Альбіоні». Охоплено також і англомовний сегмент друкованої книжкової продукції українців для чужинців та «серію антирадянських видань, що переправлялися до СРСР». Тут же - упорядкований автором системний каталог видань українців у Великій Британії.

Як і вище оглянута книга про українську журналістику у Великій Британії, ця - емоційно-енциклопедична, що загалом рідкісне явище в нашому гуманітарному просторі.

Подібні ці книги й за стилем поліграфічного оформлення, оскільки опубліковані в тому ж видавництві - «Наша культура і наука».

«На нас на чужині лежить обов'язок заховати те, що в Україні підлягає нищенню. Треба буде перевидати наукові та літературні твори, що віддзеркалюють правдиву українську думку, нефальшовані житейські цілі українського народу... Треба буде створити наші незалежні наукові та видавничі осередки. Будуть мусіти постати бібліотеки-книгозбірні, що дадуть нам добру рідну книжку, з якої і чужинці могли б виробляти собі правдивий погляд на Україну й українців».

Ця витинка із п’ятого числа лондонської газети «Українська Думка» за 1947 рік звучить у цій книзі як кредо, як бойовий мотиваційний клич, апостолований із того часу в нашу еру й далі - до нащадків, які продовжать духовну боротьбу за Україну на культурно-інформаційному полі, медіумом на якому і виступив сам професор Микола Тимошик. Про це переконливо вже констатували у своїх рецензіях на книги цього автора доктор філософії зі США Володимир Іваненко, Василь Верига із Канади, лауреат Шевченківської премії Любов Голота, професори Ірина Фаріон та Алла Бойко.

Готична архітектоніка тексту і цього видання маркована сімома розділами («Специфіка закордонного друкарства», «Початки», «Головні видавничі осередки», «Англомовне книговидання», «Підривна література для СРСР», «Лондонські сторінки української Біблії», «Проблеми каталогізації видань зарубіжного українства»), «Висно- 
вки», Додатки («Каталог книжкових видань українців у Великій Британії (Укладач проф. М. Тимошик»), «Абревіатури, що зустрічаються в тексті книги»), Іменний та предметний покажчики, Summary...

Уже сам перелік назв розділів, назв друкованих у Великій Британії книг («Джерела пошуку інформації», «Приватні видавництва», «Чому я не хочу вертатися на «родіну», «3 історії українських календарів», «Зачинатель безперервного видання українських книжок», «Друкарський верстат - у кредит», «Акція «Український «Буквар», «Проєкт «Українська пісня», «Фінансові засади видань», «Тематичний діапазон книжкової продукції», «Авторка - колишня каторжанка ГУЛАГу», «Марш молодости» від дивізійника-східняка», «Одна українська книжка проти тисячі російських», «Вибір шотландця Джона Стюарта», «Про поняття «підривна література», «Інші передруки з криївок УПА», «Степан Бандера в радянській обкладинці», «Переклад Пантелеймона Куліша з Відня», «Відновлення співпраці з британськими біблеїстами», «Медаль королеви Англії за українську Біблію»...) магічно-реалістично демонструє, зацікавлює потенційного читача-інтелектуала, репрезентанта різних сфер життя - політики, економіки, мистецтва, релігії, літератури.

Для таких читачів ця книга може апріорі стати підручником для реалізації своїх проєктів у тих же сферах, як і сигнальними маркерами є прізвища згадуваних тут людей (окрім знакових у нашій істоpiї, на кшталт Івана Мазепи, Івана Франка, Степана Бандери), серед яких Леонід Бачинський, Юрій Борець-Чумак, Володимир Вашкович, Ольга Вітошинська, Ростислав Глувко, Степан Говерля, Григорій Голоскевич, Дмитро Грицько-Цяпка, Ігор Губаржевський, Марія Дейко, Ярослав Деременда, Іван Деснянський, Богдан Казанівський, Микола Клименко, Микола Кулицький, Ізидора Левкович, Андрій Легіт, Роберт Лісовський, Михайло Ломацький, Галина Мазуренко, Михайло Марченко (Павлюк), Олег Мартович, Микола Матвіївський, Борис Матушевський, Іванка Мащак, Петро Мірчук, Михайло Млаковий, Володимир Музичка, Іван Музичка, Осип Музичка, Михайло Осадчий, Микола Павлушков, Ярослав Рудницький, Євген Рей, Микола Стаховський, Маркіян Терлецький, Вадим Щербаківський...

Попри все і вся «українці залишаються єдиною в цивілізованому світі нацією (принаймні на теренах Західної Европи), які досі не мають повного репертуару книжкових видань своєю мовою від періоду нової доби української культури», - сумно констатує у «Висновках» професор Микола Тимошик, який зробив, як бачимо, дуже багато для того, щоби цю «білу пляму» нашої історії ліквідувати, зазначаючи часопростір творення своєї Монографії: «Київ - Лондон - Манчестер Единбург - Хутір Тарасенки; грудень 2016 - серпень 2020». 
Обидві книги Миколи Тимошика гармонійно, з естетичним смаком інкрустовані чорно-білими ілюстраціями на кшталт: «Перша шпальта «Нашого Кличу», «Перше число «Українського Кличу», «Один iз редакторів «Української Думки» - відомий дослідник-українознавець Олекса Воропай».

Манера викладу цих видань настільки прозора, шліфовано-легка, а тема настільки вагома, що вони, я впевнений, зачеплять за живе всіх, кого цікавить історія України та світу, доля нашої еміграції та її найголовніших набутків на чужині - Української Книги і Преси.

Читати ці книги можна як детективні історичні романи...

Вітаємо усю прогресивну громадськість України і світу із цими двома духовними материками, книгами-формулами на британському острові, відкритими й оприявленими для всіх нас Професором Миколою Степановичем Тимошиком.

Це - Подія.

\section{СПИСОК БІБЛІОГРАФІЧНИХ ПОСИЛАНЬ}

Куди і ким спрямована національна університетська освіта і наука? Відкрите звернення до державного керівництва. (2021, 15 лютого). Слово Просвіти. http://slovoprosvity.org/2021/02/15/ kudy-i-kym-spriamovana-natsional-na-universytets-ka-osvita-i-nauka/

Романова, А. (2021, 17 лютого). В Україні назріває «науковий переворот» освітяни звернулися до Зеленського через глибоку кризу. Znaj.ua. https://breaking.znaj.ua/367894-v-ukrajini-nazrivaye-naukoviy-perevorotosvityani-zvernulisya-do-zelenskogo-cherez-gliboku-krizu?fbclid=IwAR3NpixxNRV7BIxrSnDL8Q0iPZlJrhbhUS_aTNIDm5DNjGWB-ZZ0Zn83T0Znaj.ua

Тимошик, M. (2021a, 18 січня). Українська гуманітарна наука під дамоклевим мечем «Скопусу». Слово Просвіти. http://slovoprosvity.org/2021/01/18/ ukrains-ka-humanitarna-nauka-pid-damoklovym-mechem-skopusu/

Тимошик, М. (2021b, 23 січня). «Материн заповіт у вишитому 1933 року рушнику», - професор про рідну Чернігівщину, українську діаспору, освіту та інтелігенцію з нагоди свого 65-ліття (Інтерв’юер Д. Тарусова). Міський портал Ніжина. https://m.mynizhyn.com/news/misto-i-region/18247-materinzapovit-u-vishitomu-1933-roku-rushniku-profesor-mikola-timoshik-pro-ridnuchernigivshinu-ukrayinsku-diasporu-osvitu-ta-inteligenciyu-z-nagodi-svogo-65littja.html

\section{REFERENCES}

Kudy i kym spriamovana natsionalna universytetska osvita i nauka? Vidkryte zvernennia do derzhavnoho kerivnytstva [Where and by whom is the national university education and science directed? Open appeal to the state leadership]. (2021, February 15). Slovo Prosvity. http://slovoprosvity.org/2021/02/15/kudy-ikym-spriamovana-natsional-na-universytets-ka-osvita-i-nauka/ [in Ukrainian]. 
Romanova, A. (2021, February 17). V Ukraini nazrivaie «naukovyi perevorot»osvitiany zvernulysia do Zelenskoho cherez hlyboku kryzu [A «scientific revolution» is brewing in Ukraine - educators turned to Zelensky because of the deep crisis]. Znaj.ua. https://breaking.znaj.ua/367894-v-ukrajini-nazrivayenaukoviy-perevorot-osvityani-zvernulisya-do-zelenskogo-cherez-glibokukrizu?fbclid=IwAR3Np-ixxNRV7BIxrSnDL8Q0iPZlJrhbhUS_aTNIDm5DNjGWBZZ0Zn83T0Znaj.ua [in Ukrainian].

Tymoshyk, M. (2021a, January 18). Ukrainska humanitarna nauka pid damoklevym mechem «Skopusu» [Ukrainian humanities under the sword of Damocles «Scopus»]. Slovo Prosvity. http://slovoprosvity.org/2021/01/18/ukrains-ka-humanitarnanauka-pid-damoklovym-mechem-skopusu/ [in Ukrainian].

Tymoshyk, M. (2021b, January 23). «Materyn zapovit u vyshytomu 1933 roku rushnyku», - profesor pro ridnu Chernihivshchynu, ukrainsku diasporu, osvitu ta intelihentsiiu z nahody svoho 65-littia [«Mother’s Testament in a Towel Embroidered in 1933» - a professor about his native Chernihiv region, the Ukrainian diaspora, education and intellectuals on the occasion of his 65th birthday] (Interviewer D. Tarusova). Miskyi portal Nizhyna. https://m.mynizhyn. com/news/misto-i-region/18247-materin-zapovit-u-vishitomu-1933-rokurushniku-profesor-mikola-timoshik-pro-ridnu-chernigivshinu-ukrayinskudiasporu-osvitu-ta-inteligenciyu-z-nagodi-svogo-65-littja.html [in Ukrainian]. 